\title{
Parents and Adolescents Pattern of Interpersonal Communication in The Restriction of Smartphone Usage
}

\author{
Ratih Siti Aminah*), Muslim*) \\ ${ }^{*}$ University of Pakuan, Bogor, Indonesia \\ Corresponding Author: ratih.penari@gmail.com
}

\begin{abstract}
Communication can be the media of proximity of parents and children. Parents will feel comfortable because they feel the child needs and love him. Conversely, the child will feel happy to get the attention of his parents. The development of communication technology led to a new style of communication style. Parent and child communication is no longer done face-to-face at the dinner table or in the living room. The role of interpersonal communication of parents and children began to shift since the presence of a smart tool that was created able to perform many activities.

Communication patterns between adolescent boys and girls tend to be different Young men and women have different tendencies in smartphone use. Female teenagers are more dominant using social media to upload good photographs with friends or photos themselves. Young men use smartphones to play games, download songs, movies or video clips. Teenagers in Indonesia (40-50 percent) is a community of hp (smartphone) users. Teenagers use social media that includes instant messengers like LINE, Instagram, Twitter and other apps like Facebook, Youtube, Vlog and more. There are three patterns of communication that parents do in limiting the use of smartphones in adolescents. The patterns are Authoritarian communication patterns, Democratic communication patterns and Permissive Communication Patterns.
\end{abstract}

Keywords: Communication Patterns, smartphones, restrictions

\section{INTRODUCTION}

The development of communication technology led to a new style of communication style. Parent and child communication is no longer done face-to-face at the dinner table or in the living room. The role of interpersonal communication of parents and children began to shift since the presence of a smart tool that was created able to perform many activities. Question, "Where is Mother or Brother already doing Homework? Can be delivered and answered via a communication tool called Smartphone. Although parents communicate with children (adolescents) through mobile phones (HP) and provide hp facilities, they still limit the use of hp in adolescents for various reasons ..

Restrictions on the use of smartphones (smartphones) wisely in adolescents will create a harmonious relationship between parents and adolescents. Smartphone is defined as a tool or instrument that has a specific purpose and practical function that is useful as a transmitter of information in which has many functions, among them can send and receive messages, receive and send messages, have softwarae photography, has many online gaming sites and other services (Sanjaya, 2011). This object is then a lot of time consuming users, busy with life and activities senrdiri. Parents tend to have difficulty in providing time restrictions on their children's activities with smartphones. In the face of this condition, limiting the length of time using Smartphones is imperative.

\section{Problems}

In today's era of information and communication technology advancements, smartphones have become the close friends of the world community. The presence of this small object has made interpersonal communication by meeting directly rarely done. Communication between parents and children face-to-face shifts.

This study is more in-depth to know:

1. What is the process of interpersonal communication between parents and children?

2. How to describe the use of smartphones in children?

3. What are the parent-child communication patterns in limiting smartphone usage?

\section{Research Objectives}

The purpose of this research are:

1. To know the process of interpersonal communication in parents and adolescents

2. To know the description of smartphone use in adolescents 
3. To know the pattern of interpersonal communication of parents and adolescents in the limitation of smartphone usage?

\section{Literature Review}

\section{Interpersonal Communication}

Devito (2011: 252) defines interpersonal communication from three main approaches, including:

1. By Component (Componential)

A component-based definition describes interpersonal communication by observing its key components.

2. Based on Diadic Relations (Relational [dyadic])

In a relationship-based definition, interpersonal communication is defined as the communication that takes place between two people who have a steady and clear relationship.

3. Based on Development

Interpersonal communication is seen as the end of the development of impersonal communication at an extreme into interpersonal or intimate communication at the other extreme.

Man as a social being during his life is in touch with other human beings. De Vito (2006) describes communication as a transaction. Transaction is a process in which the components are interrelated and that its communicators act and react as a whole and whole. In every transaction process, each element relates integrally to another element.

\section{Pattern of Communication}

Djamarah (2009) defines Pattern as a fixed form (structure). The pattern of communication is defined as the form or pattern of the relationship of two or more people in the process of sending and receiving the right way, so the message in question can be understood.Tubbs and Moss (1996) said that the pattern of communication or the relationship can be created by complementary or symmetry. .

From the above understanding, a communication pattern is a form or pattern of relationship between two or more people in the process pengriman and receipt of messages that link the two components, namely the picture or plan that includes the steps on an activity, with components that are an important part of the occurrence of communication between people.

\section{Pattern of Parent Communication}

Every child is born from a family. The family is the main socializing agent for a child who has the most significant influence in a child's life (Ahmad \& Braithwaite, 2004). In a family consisting of father, mother, and child usually interaction where in the process of interaction with their children, the father and mother apply certain communication patterns. There are various definitions of parental communication patterns expressed by some experts (Brooks, 2004), define communication patterns as a series of actions and interactions that parents make in fostering children's physical, psychological and social aspects. There are three goals of communication patterns mentioned by Brooks, (a) first, parents assure the physical and life health of the child; (b) secondly, preparing the child to become an adult who can meet his own financial needs; and (c) third, support or encourage positive social and personal behavior. (Martin \& Colbert, 1997) explains that communication patterns as a process that usually involves adults in childbirth, protecting nurturing, and directing children.

Parents who have good communication with their children then To interact and communicate with adolescents, parents need a certain communication patterns. Communication patterns are otherwise tailored to the characteristics of children. Based on the type of parent according to Senjaya (2011: 106) there are three types of parent communication patterns, namely:

\section{Authoritarian}

The communication pattern that determines everything. Parents assume that what they say is most true and good. Children are deemed ignorant of parents not encouraging children to be independent and make decisions related to the actions of the child. Parents just say what should or not do and do not explain why it should or not be done.

\section{Permissive}

This pattern is more likely to let the child develop by itself. Parents do not provide any signs to the child, just ignore the signs from the environment.

\section{Democratic}

This communication pattern explains why something is allowed or not to be done. Parents are open to discussing with children. Parents see the child as something to be heard, appreciated, given the opportunity. Of the three patterns, the ideal is the combination of the three.

\section{Different Mother and Father Communication Patterns}

Parents may not realize, actually the pattern of communication between father and mother is different. This is because, basically the gender of men and women are different, both in the pattern of life, background and work, the difference in the pattern of communication father and mother is very reasonable, fathers are physically stronger than mothers. Generally fathers are breadwinners (breadwinners, Red) in the family. However both must synergize each other in building a child's life. If father is more build vision and mission, and foster competence and self-confidence. While the mother is more to give love, touch, hug, give examples of affection, or invite children to chat (Verauli, 2012). In general, fathers and mothers have a similar role in the process of child care and communication in their children. 
The role of parents in communication patterns will change as the child grows and develops. Therefore parents can understand the phases of child development and balance it. According to developmental psychologist Jean Piaget, children need to take certain actions on their environment to develop a complex and intelligent perspective on each experience. It is the duty of parents to give children the experience children need for their intelligence to flourish perfectly (Verauli Erik Erikson in, 2012).

\section{Youth}

Adolescence is a transitional period of individual development from childhood to adulthood. Where at that time there was rapid development and changes in both physical, psychological and social (Potter \& Perry, 2005). Adolescence consists of three distinct sub-phases, namely: early adolescence (age 11 to 14 years), middle adolescence (age 15 to 17 years). And late adolescence (age 18 to 20 years) (Wong, et al, 2009).

Further Santrock in Dariyo (2004: 13) defines puberty as a period of bone growth and maturation that occurs in early adolescence. According to Stanley Hall in Dariyo (2004: 13) the age of adolescents between 12 to 23 years of age.

Adolescentia comes from the Latin term, adolescentia which means the youth that occurs between 17-30 years. Yulia and SinggihD. Gunarsa finally concluded that the process of psychic development

\section{Smartphone}

Smartphones (smartphones) are information or communication tools that have similar functions to computers in presenting powerful features or interesting applications in communicating, social networking, audio, video, pictures, games and other entertainment, either online or offline.

These technological developments create a competition, whereby producers or big companies are increasingly competing to offer feature and technology offerings that appeal to consumers. With a variety of features or applications in it and offer prices ranging from low prices to expensive prices, thus we can easily get and have a smart phone (smartphone). Now this smart phone (smartphone) can be owned by ups and downs, it can be one reason for everyone to use and have a smart phone (smartphone).

Smartphones (smartphones) are actually intended for people who have an interest in business, work, college and office. But now the use of smartphones (smartphones) is not only used by teenagers and adults or elderly, but used also by children and even smartphones (smartphones) are used by early childhood such as 2-6 years old children who have not worth using a smart phone (smartphone) (Shin, 2014: 97).

\section{RESEARCH METHODS}

\section{Research design}

Research conducted by the author using descriptive qualitative approach method. The data obtained and collected that focus on the subject of research comes from interviews from various sources that have credibility, activity records, and documents obtained from the object of research. This research tries to explain how the pattern of interpersonal communication between parent and child in limiting smartphone usage. The approach will be deep, detailed, and intensive without testing hypotheses.

\section{Data Collection Techniques}

Literature study is intended to obtain theories of communication and supporting theories that can provide an explanation of the issues of the issues in detail, literature study conducted among them:

\section{Literature Review}

The literature review is collecting data through literature books, previous research reports of the same kind, and other data sources, supplemented by the opinions of experts relating to the issues discussed in order to obtain theoretical data as a comparison material in the discussion of the problem. All data obtained in this way is secondary data presented by citing and revealing existing theories that relate to the research being done to support the perfection of the research results.

\section{Internet Searching}

Researchers do not arbitrarily in the search for information through the internet, researchers cite information from the official sites are valid so that the information required by the researcher is correct and reliable information.

\section{Field Studies}

Field study is the process of collecting data that is done by the researchers jumped directly to where the object of research. Field studies conducted include:

\section{Interview 2. Observation and Documentation}

\section{Types and Data Sources}

According to Lofland and Lofland in Moleong (2011: 157) the main data source in qualitative research is the words and the rest of the action is additional data such as documents, and others.

1 . Words and actions

Moleong (2011: 157) the words and actions of the observed or interviewed people are the primary data source. The main data source is recorded through written notes or through video recording / audio tapes, photo capture, or movies.

\section{Written source}

3. Photos

Moleong (2011: 160) is now more widely used as a tool for qualitative purposes because it produces 
descriptive data that is quite valuable and is often used to examine subjective aspects and the results are often analyzed inductively.

\section{Location and Time of Study}

This study discusses the pattern of interpersonal communication between parents and adolescents. therefore the researchers chose the location of the study included in Griya Housing. Griya Katulampa Housing majority consists of married couples who have elementary school age children and use smartphones, In addition, residents who live in this housing is a citizen of various social strata. The time of the research to be conducted is November 2016-May 2017.

\section{Research Subject and Informant Data}

According to Faisal (2004: 109) the term research subject to the person / individual / group that made the unit or unit (case) studied. Because case studies have an interest in the effort of "constructing" how a person or group something as a whole. The typological features of the study subjects need to be stated adequately and clearly, with regard to who, in what category they are, their general and unique features compared to other similar subjects.

In qualitative research, the researcher is an instrument so direct approach to researcher subject to obtain accurate data. Subjects studied to be discussed in the study are married couples who have elementary school age children.

The key informants and informants in this study, among others

Table 1 Key Informan

\begin{tabular}{|l|l|c|}
\hline No. & \multicolumn{1}{|c|}{ Key Informan } & \multicolumn{1}{c|}{ Notes } \\
\hline 1. & Working parents & Mother \\
\hline 2. & Non working parents & Mother \\
\hline 3. & Single parent & Mother \\
\hline
\end{tabular}

Tabel 2 Informan

\begin{tabular}{|c|c|c|}
\hline No & Informan & Keterangan \\
\hline 1 & Junior high school age & Working mother \\
\hline 2 & Junior high school age & Non working mother \\
\hline 3 & Junior high school age & Single parent \\
\hline
\end{tabular}

Determination of key informants above is conducted in this way because, according to researchers, the subject of the study has credibility in accordance with the research.

\section{Validation and Validity}

Test the validity of data in qualitative research includes several tests. Researchers use credibility test or trust test on the results of the study. Based on the techniques proposed by Moleong (2011: 326-342), among others, done with extension of participation, increased persistence in research, triangulation data, discussion with peers, referential adequacy, negative case review, member checking, detailed description, and auditing. In this study, researchers used the validity test of data by increasing persistence, and triangulation.

\section{Data Analysis Techniques}

In doing this research the researcher use qualitative approach,

\section{RESULTS AND DISCUSSION}

\section{Interpersonal Communication Process of Parents and Children}

Interpersonal communication is defined as an ongoing communication between two people who have a firm and clear relationship. Sometimes this definition is expanded to include also a small group of people, such as family members or groups of three or four people.

In the interpersonal communication process parents and children describe communication as a transaction. Transaction is a process in which the components are interrelated and that its communicators act and react as a whole and whole. In every transaction process, each element relates integrally to another element.

In this transaction, sometimes the parent becomes a messenger (Communicator) who reminds his child to worship, study and other messages either face to face, through an intermediary of hp media (smartphone) by calling or sending messages to the child who is called a communicant. On another occasion, the child can be a messenger (communicator) and parents as the recipient of the message (communicant).

The existence of Communicator, message content, communicant and media (messenger tool) and response (feedback) is always an element in a communication process, including interpersonal communication (interpersonal communication). Messages sent parents and received by children or vice versa can also experience disruption caused by many things, among others, the telephone network is experiencing interference, the message is not directly responded to busy communicant or psychological and other reasons. Every parent has a different way of communicating with her child. In the current state of information and communication technology development requires parents to be able to adjust to the development of the current state of social and social life of teenagers.

\section{Interpersonal Communication Process of Working and Adolescent Mothers}

Working mothers tend to be more open in communicating with adolescents (their children). Damayanti rarely ask about things like have eaten or not because according to him kayo already understand when to eat. Different thing done Sari mother of Sandi (14) year. Boys' passwords, sometimes like to ignore the important things such as lunch that I bring not eaten 
or just eaten a little bit with full excuse or do not like the menu that I bring. Once a few times that my lunch was not eaten, he ended up two days of school because of stomach pain. This is what keeps me every day reminding Password continues. If I remind him he was quiet, maybe because men so not much talk ".

In contrast to Sjanti, a working mother who is a single parent. Her son is very familiar with her. His condition as a single parent makes him very worried about Rafi (16). However, his concerns actually make his son often protest. .

\section{Interpersonal Communication Process Mother Not Working and Adolescent}

The content of messages delivered by mothers, whether working or not working or who are single parents, tends to be similar, more to recall messages almost daily delivered. Teenagers, whether male or female, tend to feel bored with the daily messages that the mother delivered. Their reaction to the message delivered by the mother tends to be the same that is not a word and leave the mother and then go into his room or answer the mother's questions lazily and reluctantly.

\section{Description of Smartphone Use of Youth}

According to data from the Central Bureau of Statistics (2015), out of about 250 million Indonesians currently around 34.47 percent or about 82 million people aged between 15-34 years. According to Milward Brown in Smart Millenials Intelligent Millenials (2016), in one day Indonesian teenager for 291 minutes spent time in front of the smartphone screen and tablets. Smartphones (smartphones) are information or communication tools that have similar functions to computers in presenting powerful features or interesting applications in communicating, social networking, audio, video, pictures, games and other entertainment, either online or offline.

Currently smartphone is absolutely owned by all people in the world, especially teenagers.In schools or courses or other places that become daily activities, teenagers are also on the move with a smartphone. At this time they usually download information to do schoolwork, contacting parents, friends, friends, family or other individuals, eg tutors at the tutoring place, drivers, or other individuals. Teenagers also send photos and upload photos of activities performed on that day while updating status or comments on their social media.

Male and female adolescents have different trends in smartphone usage. Female teenagers are more dominant using social media to upload good photographs with friends or photos themselves. This is as revealed by Khalida (13). "I almost upload (upload) photos and make comments (comments), comment on other people's posts or comment on posts themselves Different things done Sandi (14), students kls VIII one State Junior High School in Bogor. "I mostly use the smartphone to play games, download songs, movies or video clips

\section{Pattern of Parent Communication Patterns in the Smartphone Use Restrictions}

The pattern of communication is a series of actions and interactions that parents do in helping the child's development both physical, psychological and social aspects. There are three goals of the first communication pattern, the parent ensures the physical health and the child's life; Second, to prepare children to become adults who can meet their own financial needs; Third, support or encourage positive social and personal behavior.

\section{Description of Smartphone Use of Youth}

According to data from the Central Bureau of Statistics (2015), out of about 250 million Indonesians currently around 34.47 percent or about 82 million people aged between 15-34 years. According to Milward Brown in Smart Millenials Intelligent Millenials (2016), in one day Indonesian teenager for 291 minutes spent time in front of the smartphone screen and tablets. Smartphones (smartphones) are information or communication tools that have similar functions in communicating, social networking, audio, video, pictures, games and other entertainment, either online or offline.

Currently smartphone is absolutely owned by all people in the world, especially teenagers.

In school or courses or teenagers are also on the move with a smartphone. At this time they usually download information to do schoolwork, contacting parents, friends, friends, family or other individuals, eg tutors at the tutoring place, drivers, or other individuals. Teenagers also send photos and videos on their social media.

Male and female adolescents have different trends in smartphone usage. Female teenagers are more dominant using social media to upload good photographs with friends or photos themselves. This is as revealed by Khalida (13). "I almost upload (upload) photos and make comments (comments), comment on other people's posts or comments on posts themselves

Different things done Sandi (14), students kls VIII one State Junior High School in Bogor. "I mostly use the smartphone to play games, download songs, movies or video clips. In contrast to Damayanti, Susi, the mother of Khalida would rebuke her son if he came home late and did not provide news on any grounds.

Santi, the mother of Rafi often had to be firm with her son. I take full responsibility for Rafi's growth and development. As a mother sometimes I have trouble understanding her thoughts and wishes, maybe because I am female, so do not understand the teenager's thinking age. Rafi still obeys the rules. I see he is more comfortable if I invite discussion rather than my ultimatum ". 
Damayanti, Susi and Sjanti have different patterns in limiting the use of smartphones in adolescents. Susi is more representative of authoritarian communication pattern in her teenage child (Khalida). Rules Susie made as a parent (Mother) absolutely determines everything. As Susi's parents thought that what she did was the most correct and good. Susi did not discuss the rules she made to Khalida (no discussion). Khalida is obliged to obey the rules his parents made.

Permissive Communication Pattern conducted by Damayanti to her teenage child Kayo. As a mother, Damayanti tends to let the child develop by itself.Damayanti tends to adapt to the environment suitable for Kayo, although sometimes there are conditions that do not fit, Damayanti will try to adjust it. This condition is often used Kayo to find loopholes in order to get more permission to move with the smartphone.

The pattern of communication between Sjanti and Rafi is a democratic pattern of communication. In a sense, as a parent (mother), Sjanti will be assertive by angry and confiscate Rafi's smartphone if the rules and agreements that have been made are violated. Consequences remain given when Rafi conduct offenders. However, Sjanti did not shut down to review the rules he made if there was a logical reason. Rafi must tolerate the consequences of his offense. Sjanti as a mother also learns to adjust to the environmental and emotional and psychological state of her teenage child.

As a parent, Sjanti is open to discussing with his son and giving Rafi the opportunity to express his thoughts and explain the problems facing his teenage child. Sjanti tried to hear and understand it.

\section{CONCLUSION}

1. The process of interpersonal communication of parents and adolescents can be initiated with parents as Communicators (messenger) in adolescents (communicant), At other times, adolescents can act as Communicators by giving a message to parents (communicant). Teenagers deliver and respond to messages sent their parents through hp (smartphone) it has.

2. Teens use hp (smartphone) to communicate with parents and friends using social media Instagram, Twitter, Line, Vlog, and also Youtube app. Teenagers also take advantage of other facilities available on the internet by using hp to do school work and find information about things that can support his hobby.

3. Every parent has a different pattern of communication with her teenage child. There are parents who apply authoritarian, permissive and democratic patterns.

\section{Suggestions}

1. Parents in applying smartphone restriction rules are wiser to include children (teens) in creating rules. In addition, parents must be assertive to the child (teenager) if a violation of the agreement that has been made.

2. In today's era of information and communication technology advancement, parents should be able to adapt to the environment that adolescents face today.

\section{REFERENCES}

DeVito, Joseph. 1997. Komunikasi Antarmanusia. Jakarta. Professional Books.

Djamarah, B.S. 2004. Komunikasi Orangtua dan Anak dalam Keluarga. Jakarta: Rineka Cipta.

KMPlus Consulting. 2016. Smart Millenials Generasi Millenials yang Cerdas Jakarta: Penerbit PT Gramedia Pustaka Utama

Moleong, L.J. 2007 .Metodologi Penelitian Kualitatif. Bandung: Remaja Rosdakarya.

Mulya, Prasetya Publishing. 2013. Social Media Nation 15 Inspirasi Berjejaring Sosial. Jakarta

Rakhmat Jalaludin, 2005. Psikologi Komunikasi. Bandung. Remaja Rosdakarya.

Sanjaya, Ridwa dan Christine Wibowo. 2011. Menyiasati Tren Digital pada Anak .Jakarta: PT Elex Media KomputindoKelompok Gramedia.

Moss, Sylvia dan Tubbs, Stewart L. 2000 . Human Communication Prinsip-Prinsip Dasar.Bandung: Remaja Rosdakarya. 